\title{
Inter-Linkage between Credit Source and Marketing Pattern of Farm Produce
}

\author{
Lovepreet Singh* and Arjinder Kaur
}

Department of Economics and Sociology, Punjab Agricultural University, Ludhiana-141004, Punjab, India

*Corresponding author: lovepreetpau94@gmail.com (ORCID ID: 0000-0002-3905-3500)

Received: $22-08-2019$

Revised: $24-01-2020$

Accepted: 26-02-2020

\begin{abstract}
The present study has been undertaken in three agro-economic zones of Punjab to examine the linkages between the credit source and marketing pattern of farm produce. Multistage random sampling technique was used for the selection of 90 farmers. Inter-linkages between the source of credit and marketing pattern refer to the inter-linkage between farmers and moneylender indulged in trading activities. Majority of the sampled farmers i.e. 65 per cent were found trapped in linked transactions. Participation of medium farmers in linked credit contracts was found to be higher i.e. 72.22 per cent as compared to large (57.14\%) and small farmers $(51.72 \%)$. Credit-input-product inter-linkage emerged as dominant type in the study area i.e. 33.33 per cent followed by credit-product type (31.11 per cent).

\section{Highlights}

(0 It was concluded that there were inter-linkage between the source of credit and marketing pattern of farm produce among the sampled farmers.

(- Participation of medium farmers in linked credit contracts was found to be higher due to large size of marketable surplus.
\end{abstract}

Keywords: marketing pattern, farm produce,credit,linkages

Existence of inter linkages among the land, labour, credit and product markets is one of the often noted feature of less developed agrarian economies. The functioning of informal credit market in the rural credit system leads to development of linkages with other markets such as labour, input, output and land lease market (Bell et al. 1988 and Reddy, 1992). Inter-linkage between the source of credit and market produce refers to the linkage between farmers and moneylenders indulged in trading activities. These moneylenders may be landlords who finance his tenants or workers engaged on land; he may be a trader called commission agent in modern nomenclature, financing the cultivator only to obtain exclusive rights to purchase his crop; or he may be an input dealer who lent money on the condition that inputs for cultivation were purchased only from him. The concept of inter-linkage has probably been borrowed from anthropology, where the multistranded nature of relationships in small, face-toface communities has often been emphasized. Such societies have been called multiplex, and multiplex relationships between the same economic agents in poor agrarian community are often described as interlinked contracts encompassing several markets, particularly those of land, labour and credit (Gill, 2004).

Inter-linked transaction is the one that involves the individuals in trade, in at least two markets to join on the condition that the terms of all trade transactions between them are jointly determined (Bardhan, 1980 and Bell, 1988). The nature of linkages depends on the relative bargaining power of the parties involved

How to cite this article: Singh, L. and Kaur, A. (2020). Inter-linkage between credit source and marketing pattern of farm produce. Economic Affairs, 65(1): 123-128. 
in the credit transactions, relative urgency of availing credit and availability of alternative source of credit. Hence, the linkage may be either beneficial to both the parties involved in credit transaction or disadvantageous to the weaker party (Reddy, 1992).

The pattern and consequences of inter linked credit markets have been a subject of controversy for quite some time. There were two major arguments on the effect of inter linkages. One was that the inter linkages have been utilized as an exploitive device by stronger parties to extract surplus out of the weaker ones (Bhaduri, 1986; Bharadwaj, 1974). The other one, while rejecting inter linkage being necessarily exploitive, explained it's rationale in terms of information asymmetry and uncertainty (Braverman and Stiglitz, 1982). It has also been used as enhanced enforcement device for execution of contracts and reducing the transaction costs in the requirement of wage labourers (Bardhan, 1984 and Ray, 1998). Further, it has been pointed out that inter linking is a flexible market response to growing commercialization (Bell and Srinivasan, 1989).

Moneylender provides tied loan to the farmers, who finances the cultivator with some binding to buy the output or sell the inputs or to get assured supply of labour. This observation about the dual role of the moneylender is not new, References having been made to it, wayback as in 1925 by Darling. Moneylenders further sell this produce to the government agencies. Payment on sale of crop is also made through moneylenders, who deduct their loan amount before finally paying to the cultivators their returns. In this way credit gets linked with the output.These links have got strengthened with growing commercialization in agriculture of Punjab. In this way, commission agents have displayed a greater foresight than institutional sources of finance, and inter linkages have been continuously emerging between rural credit market and input/product markets. So, the purpose of this study was to have an in depth analysis of these inter-linkages in the state.

\section{MATERIAL AND METHODS}

The present study was conducted in all the three agro-economic zones of Punjab state during the year 2015-16. Multistage random sampling technique was used to select the respondent farmers. At first stage, one district was selected randomly from the each zone. Shaheed Bhagat Singh Nagar (erstwhile
Nawanshahr) was selected from the Zone-I i.e. submountainous zone, Barnala was selected from the Zone-II which is the central zone and Bathinda was selected from the Zone-III i.e. south-western zone of the state. At the second stage of sampling, one block was selected from the selected district. At next stage two villages were selected from each selected block. At the last stage, fifteen farmers were selected from each village falling under three categories based on the size of operational holding defining small (up to 5 acres), medium ( $>5$ acres up to 25 acres) and large ( $>25$ acres) farmers. Thus, a sample of 90 farmers covering six villages, three blocks and three districts of Punjab was finally chosen for the ultimate analysis.

In order to identify the factors influencing probability of inter-linkage between credit market and input/output market, logit regression analysis was undertaken by applying the following algebraic equation:

$$
\log \frac{P_{i}}{1-P_{i}}=\beta_{0}+\sum_{j=1}^{k} \beta_{j} \cdot X_{i j}
$$

Where,

$P_{i}=$ Probability of being linked

$1-P_{i}=$ Probability of not being linked

This dependent variable was taken as dummy variable,

1 if the household is linked; 0 otherwise

$\beta_{0}=$ Constant term

$X_{i j}=$ Explanatory variables

$\beta_{j}=$ Regression coefficients of $X_{i j}$

The explanatory variables were taken as under:

$X_{1}=$ Size of operational holding (owned land + leased in-leased out)

$X_{2}=$ NFI: FI (ratio of non-farm income to farm income)

$X_{3}=$ MW: TW (ratio of male worker to total workers)

$X_{4}=$ NLIGA (amount of per capita income generated by non-land assets/day)

$X_{5}=$ General household expenditure other than routine family expenditure/day

$X_{6}=$ Education level of the head of the family (year of schooling) 


\section{RESULTS AND DISCUSSION}

\section{Socio-economic profile of sampled farm households}

Socio economic profile of the sampled households clearly brought out that majority of respondent farmers (56.67 per cent) belonged up to 40 years of age group, while 54.44 per cent were having a family size up to five members. On overall basis, average size of operational holding of the sampled farmers was worked out to be 11.56 acres. Out of this, owned area comprised 9.8 acres, while leased in was 2.38 acres andleased out was only 0.62 acres. The extent of average annual net income earned by the sampled households from all sources came out to be ₹ 376354 per household comprising farm income at 91.16 per cent and rest of non-farm income. The average annual expenditure worked out to be ₹ 236303 per household of sampled farmers. On the other hand, average annual general expenditure (other than routine household expenditure including social/religious ceremonies, construction of house, major medical expenses, purchase of durables etc.) was measured at ₹ 180618 per household per annum of the sampled farmers. Out of the total general expenditure, the proportion of expenditure on marriage ceremonies was maximum at 40.48 per cent. It was found that sampled farmers were borrowing more from institutional sources for both the short and long term credit needs and commercial banks were their main suppliers of credit. Farmers were found to be selling their produce through different channels such as commission agents, directly to the consumers and to others as well (shellers, atta chakkies) in the study area. Majority of the farmers were found selling their produce through commission agents (81.11 per cent) followed by direct sale to consumers (13.33 per cent) and rest to others (5.56 per cent). The farmers who sold their produce through commission agents, were also found borrowing and purchasing inputs from them. In this way they were found to be trapped in linked contracts.

\section{Sources of agricultural credit availed by sampled farm households}

Source and category wise credit availed by sampled farms for short term credit needs has been shown in Table 1. Table 1 showed that on the overall basis, 25.56 per cent of the sampled farmers were borrowing only from institutional sources, while 14.44 per cent only from non-institutional sources and 60 per cent of the sampled farmers were found to be availing credit from both the sources. So, incidence of borrowing in terms of number of borrowers from institutional sources was found to be higher on sampled farmers as compared to noninstitutional sources.

Category-wise 31.03 per cent of the small farmers were borrowing from the institutional sources whereas the respective figures for the medium and large farmers were 22.22 per cent and 28.57 per cent. On the other hand, 27.58 per cent small farmers were tapping the non-institutional sources of credit, whereas the respective figure for the medium farmers was 9.26 per cent. None of the large farmer was found to be borrowing only from non-institutional sources. In case of both (those farmers which were borrowing from both institutional as well as non-institutional sources), 41.38 per cent were in small farm category, while 68.51 per cent and 71.43 per cent in medium and large farms respectively. So, it was concluded that sampled farmers belonging to all the farm categories borrowed more from institutional source of credit for short term credit needs.

Table 1: Source and category wise sampled borrower farmers for short term credit needs in Punjab, 2015-16

(Number)

\begin{tabular}{llll}
\hline Household & \multicolumn{3}{c}{ Source of borrowing } \\
\cline { 2 - 4 } category & Institutional & $\begin{array}{l}\text { Non- } \\
\text { institutional }\end{array}$ & Both \\
\hline Small & $9(31.03)$ & $8(27.58)$ & $12(41.38)$ \\
Medium & $12(22.22)$ & $5(9.26)$ & $37(68.51)$ \\
Large & $2(28.57)$ & - & $5(71.43)$ \\
\hline Total & $23(25.56)$ & $13(14.44)$ & $54(60.00)$ \\
\hline
\end{tabular}

Figures in the parentheses indicate the percentages to total number of farmer of respective farm category.

\section{Types of inter-linkages}

In this section some important types of interlinkages have been discussed which emerged between source of credit and marketing pattern of sampled farmers.

\section{Credit-product linkage}

It was noticed that marketing of the farm products 
was linked with availing of non-institutional credit. Under this system of inter-linkages, borrowers get credit from the commission agents (Arthiyas) to fulfill his production as well as consumption needs. Lenders supply credit on the condition that produce would be sold through them. The repayment of loan amount was done by selling the produce through commission agents in regulated market. In this way lender gets dual benefit, one by selling the produce on commission basis and second by charging high rate of interest from the borrower. An often noted feature of rural economies is that returns from agriculture were low and insufficient for internal financing. Under such conditions money lenders secure these clients by providing them credit on the condition that marketing of produce wouldbe routed through them. Thus, more commonly, availing of non-institutional credit turns to be a tied loan leading to credit-product inter-linkage.

\section{Credit-input-product linkage}

Another form of inter-linkage, associating in both backward and forward directions was found to be prevalent to a large extent in the study area. This was linking of farmers with input supply source as well as with marketing of produce through credit. Here, the lender was either a commission agent or a trader. Lender was supplying credit not only in cash terms but also in kind, in the form of inputs like fertilizers, pesticides, seeds etc. Sometimes they were also dealing in household items or utilities like grocery, jewellery articles, clothing etc. and forcing the borrowers to get these utilities from their outlets. Loan was supplied on the condition that sale of the produce will be made through them and in this way, repayment of the loan was realized at the time of sale of crop. This is again a type of tied loan. In this form of inter-linkage, advantage of trader/commission agents gets trebled in the way, one by charging high price of inputs and the other by selling the produce in regulated market on commission basis besides charging exorbitant rate of interest. They were also getting assured supply of marketed surplus.

The types of inter-linkages existing between credit and marketing pattern in the study have been highlighted in Table 2. On overall basis, out of total sampled farmers 64.44 per cent farmers were trapped in linked contracts. Participation of medium farmers in linked credit contract was found to be higher at 72.22 per cent as compared to large $(57.14 \%)$ and small farmers $(51.72 \%)$. The reason could be traced to the size of marketable surplus of the produce, thus leading to bargaining power of the farmer.It was observed that medium and large farmers sold 74.70 and 89.23 per cent of their total produce during the rabbi season while the respective figure for small farmers were 32.17 per cent.

Table 2: Types of inter-linkages in the credit market of the Punjab, 2015-16 (Number)

\begin{tabular}{lllll}
\hline $\begin{array}{l}\text { Types } \\
\text { of inter- } \\
\text { linkages }\end{array}$ & Small & Medium & Large & Overall \\
\cline { 2 - 4 } $\begin{array}{l}\text { Credit- } \\
\text { product }\end{array}$ & $3(10.34)$ & $23(42.59)$ & $2(28.57)$ & $28(31.11)$ \\
$\begin{array}{l}\text { Credit-input- } \\
\text { product }\end{array}$ & $12(41.37)$ & $16(29.62)$ & $2(28.57)$ & $30(33.33)$ \\
\hline Total & $15(51.72)$ & $39(72.22)$ & $4(57.14)$ & $58(64.44)$ \\
\hline
\end{tabular}

Figures in the parentheses indicate the percentages to total.

It was found that on overall basis about 31 per cent of the sampled farmers were committed in credit-product contracts. Category wise 42.59 per cent of medium farmers and 28.57per cent large farmers and about 10.34 per cent of small farmers were found to be interlinked with non-institutional credit source and marketing of their produce. This showed that medium and large farmers were more inter-linked to credit source for marketing of farm produce as compared to small farmers. The large quantity of marketable surplus could be the reason behind it, while marketable surplus with small farm category is normally less and so extent of this type of inter-linkage could get diluted.

On the other hand, input-credit-product interlinkage comprised a share of 33.33 per cent in the study area as a whole. It was found to be higher in small farm category, where 41.7 per cent of sampled farmers were interlinked in purchase of inputs as well as to dispose of their produce. The extent of interlinked farmers in this type was 29.62 per cent among medium and about 28.57 per cent in large farm categories respectively. It showed that large farmers were less tied in this type of inter-linkage as compared to small and medium farmers.

Similar type of result found by Gill (2004) in her study that the inter linkage of credit to output 
was strongest in Punjab. The commission agents or arthiyas were the most dominant source of the credit in the study region. The dominant mode of lending was cash and inputs (seeds, fertilizers, etc.), while crop was the main mode of repayment. The tying of credit with both input and output was also observed. This could be due to the relatively difficult access of cultivator to the input outlets, and hence greater control of lenders over borrowers. It was observed from the study that lenders prefer crop as collateral than other form of surety. Recovery had thus been made easier, because it was done at the time of sale of crop. By shifting to a better collateral (crop, instead of land) these lenders not only strengthened their bargaining power in their principal activity, but were also able to exploit the borrowers to the hilt by charging exorbitant rates of interest.

\section{Analysis of inter-linkages of sampled farmers across the zone}

Punjab is divided into three broad agro-economic zones namely sub-mountainous zone (zone I) having cropping pattern of wheat-maize, central zone (zone II) having cropping pattern of wheatpaddy and south-western zone (zone III) with wheat-cotton as the dominant cropping pattern. A comparative status of interlinked farmers in terms of credit and marketing pattern across the zones has been given in Table 3 .

Table 3: Inter-zonal analysis of inter-linkages of sampled farmers in Punjab, 2015-16 (Number)

\begin{tabular}{lllll}
\hline \multirow{2}{*}{ Inter-linkages } & \multicolumn{3}{c}{ Zones of Punjab } & \multirow{2}{*}{ Overall } \\
\cline { 2 - 5 } & Zone I & Zone II & Zone III & \\
\hline $\begin{array}{l}\text { Credit-product } \\
\text { Credit-input- }\end{array}$ & $7(23.66)$ & $12(40.00)$ & $11(36.66)$ & $28(31.33)$ \\
product & $12(40.00)$ & $11(36.66)$ & $30(33.33)$ \\
\hline Total & $12(40.00)$ & $24(80.00)$ & $22(73.33)$ & $58(64.44)$ \\
\hline
\end{tabular}

Figures in the parentheses indicate the percentages to total.

It showed that percentage of linked household was more in zone II i.e. 80 per cent, where as it was 73.33 per cent in zone III and 40.00 per cent in zone I. A similar trend was observed in both types of inter-linkages existing between credit sources and marketing pattern of farm produce/inputs i.e. both were found to be higher in zone II. Zone II was pre-dominantly the wheat-paddy zone and majority of the farmers were selling their produce through the commission agents, whereas marketing of cotton and maize crops was not regulated with no effective MSP (Minimum Support Price) existing in other two zones of the state.

\section{Factor affecting inter-linkage between credit source and marketing pattern of farm produce}

The factors affecting probability of linkages were identified by applying Logit form of regression. The results for overall sampled respondents in Punjab have been presented in Table 4 .

Table 4: Regression analysis of factors affecting the probability of linkages

\begin{tabular}{ll}
\hline Variables & $\begin{array}{l}\text { Regression } \\
\text { coefficients }\end{array}$ \\
\hline Constant & $\begin{array}{l}21.88^{* *}(0.018) \\
\text { Size of operational holding }\end{array}$ \\
$\begin{array}{l}\text { Ratio of non-farm income to farm income } \\
\text { (NFI:FI) }\end{array}$ & $-9.99^{* *}(0.04)$ \\
$\begin{array}{l}\text { Ratio of male workers to total workers } \\
\text { (MW:TW) }\end{array}$ & $-32.04^{* * *}(0.10)$ \\
$\begin{array}{l}\text { Income generated by non-land assets } \\
\text { (NLIGA) }\end{array}$ & $-0.03^{*}(0.006)$ \\
General household expenditure & $0.003^{* * *}(0.077)$ \\
Education (Years of schooling) & $-0.18^{\mathrm{NS}}(0.23)$ \\
$\mathrm{R}^{2}$ & 0.654 \\
\hline
\end{tabular}

Figure in the parenthesis indicate calculated p-value; NS- non significant; *, **and ${ }^{* * *}$ significance at one per cent, five per cent and ten per cent respectively.

The value of $\mathrm{R}^{2}$ in the model has come to be 0.654 , it showed that factors included in the model explained 65.4 per cent probability of farmers getting linked with credit source for market transaction. The role of operational holding came out to be negative but statistical significant (-0.19) meaning thereby that probability of linkages gets diminished with the increase in the size of operational holding as it may be argued that farmer with higher operational holding would receive better credit support, in both the formal and informal credit market as well as remunerative prices for the large quantity of marketable surplus. The ratio of non-farm income to farm income was also negative and statistical significant (-9.90). This illustrated that as the proportion of non-farm income to farm income increased, the probability of linkage gets decreased because the household having higher ratio of non- 
farm income to farm income were likely to have higher gross family income and having lesser dependence on commission agents for their routine expenditure, so less chances to enter into linked credit contracts. Further, the ratio of male workers to total workers was also found to be a negatively significant factor (-32.04) and it depicted that as the proportion of male workers to total workers was increasing, probability of linkages was decreasing because the probability of getting employment by the male workers was higher, possibly because they are absorbed for varied types of work and at distant locations as well. So, the household with higher ratio of male workers to total workers were likely to have higher income and hence they were unlikely to borrow under unfavorable terms and conditions. Similar was the case of income generated by non-land assets. Its results were negative and statistical significant (-0.03), thereby showing that as the income from non-land assets gets increased, probability of linkage gets decreased, because the households having some non-land income generating asset such as livestock, poultry or goats were having some regular cash flow through-out the year. These households thus were less likely to go for tied loans. The general household expenditure incurred by sampled farmers other than their routine family expenditure was found to be a positively significant factor (0.003). This showed that as the expenditure on general household item heads like marriages, major medical expenditure, house construction etc. gets increased, probability of linkages gets increased, as farmers were borrowing more from non-institutional sources for these purposes and prevalent mode of repayment was interlinked contracts. This further leads to sort of vicious circle i.e. current borrowing leading to contract, repayment through sale of output, next borrowing and so on. In this way they get trapped in linked contracts. The regression coefficient of education was non-significant. This indicated that education had no significant effect on probability to be linked or otherwise.

\section{CONCLUSION}

The marketing pattern of farm produce (major two crops i.e. wheat and paddy) of sampled farmers showed that majority $(81.11 \%)$ were selling their produce through commission agents in regulated markets due to convenience in sale and ease in repayment of loans. None of the sampled farmers was found to be selling the farm produce directly to government agencies despite the provision allowed by government. Majority of the sampled farmers i.e. 64 per cent were found trapped in linked transactions. Credit-input-product interlinkage was found to be of dominant type followed by credit-product inter-linkage. Size of operational holding, ratio of non-farm income to farm income, ratio of male workers to total workers and income from non-land assets were the factors inversely affecting the probability to be in linked transactions, whereas the general household expenditure (social/ religious ceremonies, house, purchase of durables etc.) was having a positive effect. So, the need is to go for building of non-land assets and to improve the share of non-farm income to break the vicious circle of inter linkage and improve the competitive strength of farmers in the marketing transactions of both output as well as inputs,

\section{REFERENCES}

Bardhan, P.K. 1980. Interlocking factor market and agrarian development: A review of issue. Oxford Eco. Pap., 32: 82-98.

Bardhan, P.K. 1984. Land, labour and rural poverty. Oxford University Press, New Delhi.

Bell, C. 1988. Credit Markets and Interlinked Transactions. Handbook of Development Economics, Vol 1, Elseneia science publishers, Netharland.

Bell, C. and Srinivasan, T.N. 1989. Interlinked transactions in rural markets: An empirical study of Andhra Pradesh, Bihar and Punjab. Oxford Bull. of Econ. and Stat., 51: 73-83.

Bhaduri, A. 1986. Forced Commerce and Agrarian Growth, World Dev., 14: 267-72.

Bhardwaj, K. 1974. Production conditions in Indian agriculture. Cambridge University Press, Cambridge.

Braveman, A. and Stiglittz, J.E. 1982. Share-cropping and the interlinking of agrarian markets. Amer. Econ. Rev., 72: 695-755.

Gill, A. 2004. Interlinked agrarian credit markets: Case study of Punjab. Econ. and Pol. Wkly., 39: 3741-51.

Ray, D. 1998. Development Economics. Oxford University Press, Delhi.

Reddy Narayana, M.V. 1992. Inter-linkages of credit with factor and product market: A study in Andhra Pradesh. Ind. J. Agri. Econ., 47: 619-29. 